\title{
Pendampingan Aktif Sejawat untuk Mengatasi Kecemasan Berbicara Bahasa Inggris: Studi Kasus Pembelajar Vokasi
}

\author{
Yerly A. Datu \\ Politeknik Ubaya, Surabaya, Indonesia \\ Email:yerly@staff.ubaya.ac.id
}

\begin{abstract}
:
Speaking anxiety becomes one of the toughest barriers in EFL learning. In the meantime, speaking competence is paramount for vocational graduates at job market. Therefore, big and continuous efforts must be done to maximize the learning outcome. This paper aims to examine how active and guided peer mentoring among learners can actually decrease anxiety of vocationa learners. For the purpose, qualitative research employing a case study design involving fourteen participants of vocational learners taking Speaking II was conducted. Stages including peer mentor screening, peer mentor preparation for guidance, peer mentoring activities, peer mentoring monitoring were applied. Responses from Focus Group Discussions (FGD) among mentors and participants being mentored were collected and analyzed afterwards. Recommendations were also made from best practices generated.
\end{abstract}

Key words: speaking anxiety, EFL learning, peer mentoring

Intisari:

Kecemasan berbicara Bahasa Inggris menjadi kendala terberat dalam pembelajaran Bahasa Inggris sebagai bahasa asing (English as a Foreign Language/EFL). Saat yang sama, kompetensi berbicara Bahasa Inggris merupakan faktor penting bagi lulusan vokasi dalam dunia kerja. Oleh karenanya, upaya besar serta berkelanjutan untuk memaksimalkan hasil pembelajaran harus dilakukan. Penelitian ini akan memaparkan tentang bagaiman pendampingan sejawat secara aktif dan terpandu dapat mengurangi kecemasan pembelajar vokasi ini. Untuk mencapai tujuan ini, penelitian kualitatif dengan menggunakan pendekatan studi kasus dilakukan. Penelitian ini melibatkan pembelajar vokasi Bahasa Inggris yang terdiri dari empat belas responden yang sedang mengambil mata kuliah Speaking II. Tahapan-tahapan yang dilakukan adalah seleksi mentor, persiapan mentor, aktivitas mentor, monitoring dan evaluasi mentor. Respon dari Focus Group Discussion diantara mentor dan mentee dikumpulkan lalu dianalisa. Rekomendasi yang diperoleh dari best practice dalam proses pendampingan juga diberikan dalam penelitian ini.

Kata Kunci: Kecemasan berbicara, pembelajaran Bahasa Inggris sebagai bahasa asing, pendampingan sejawat 


\section{Pendahuluan}

Lulusan vokasi Bahasa Inggris Bisnis diharapkan mampu mengaplikasikan keterampilan komunikasi yang diperoleh di perkuliahan dalam bidang-bidang kerja seperti Public Relations (PR), Customer Service (CS) maupun Export Import (Exim). Jenis-jenis pekerjaan tersebut sangatlah menuntut kompetensi berbicara secara aktif dan kepercayaan diri tinggi sesuai dengan fungsi-fungsi yang diperankan. Oleh karenanya, kepercayaan diri dalam berbicara menjadi faktor penting yang harus ditekankan dalam proses pembelajaran.

Banyak pakar menyatakan bahwa keterampilan berbicara Bahasa Inggris merupakan momok bagi semua pembelajar Bahasa Inggris baik sebagai bahasa asing (EFL) maupun bahasa kedua (ESI) meskipun keterampilan ini banyak diminati karena ingin menjadi pengguna aktif Bahasa Inggris (Ur, 1996). Konteks EFL berdampak pada lingkup penggunaannya yang terbatas. Keterbatasan inilah yang menjadikan penguasaan kompetensi berbicara Bahasa Inggris menjadi keterampilan yang sulit bagi pembelajar Bahasa Inggris sebagai bahasa asing (Richards, 2008).
Karakteristik pembelajaran Bahasa Inggris yang hanya ada di kelas menjadi kendala umum yang berdampak psikologis bagi pembelajarnya.

Berbeda dari pembelajar usia dini yang cenderung lebih mudah untuk masuk ke lingkungan pembelajaran baru, pembelajar dewasa memiliki tingkat kesadaran yang jauh lebih tinggi akan keadaan sekitarnya yang berpengaruh pada tingkat keenganan atau kecemasan masing-masing individu. Tingkat keengaan atau kecemasan ini merupakan bentuk nyata variasi akan respon terhadap lingkungan sekitarnya (Ellis, 1994).

Keberhasilan seseorang dalam berbicara Bahasa Inggris tampaknya dipengaruhi oleh situasi atau suasana yang mendukung sehingga yang bersangkutan bisa merasakan kenyaman dan bebas untuk mengungkapkan pendapat yang menjadi proses penting untuk tercapainya kompetensi berbicara seorang individu. Selain faktor kognisi dan kecerdasan berbahasa, faktor afektif telah menjadi faktor yang sangat berpengaruh mencapai keberhasilan berbicara Bahasa Inggris. Konsep diri, persepsi diri, cara pandang dalam melihat kondisi sekitar serta cara meresponnya 
dalam satu konteks pembelajaran menjadi elemen penting.

Faktor psikologis seperti perasaan cemas (speaking anxiety) menjadi penghalang terberat bagi pembelajar.

Jika seorang pembelajar tidak menggunakan atau berbicara Bahasa Inggris dalam sebuah situasi atau proses pembelajaran, maka itu dikatakan sebuah kegagalan (Harmer, 2001). Beberapa studi mengungkap beberapa penyebab terjadinya kecemasan berbicara. Pertama, suasana atau situasi dimana mereka harus berhadapan dengan penutur asli Bahasa Inggris (Woodrow, 2006). Dalam penelitiannya, responden yang terlibat dalam penelitian ini tidak memiliki keterampilan bagaimana mengatasi kecemasan yang dialami oleh mereka. Disamping itu cara pengajar dalam merespon serta mengatasi kecemasan mereka juga menjadi faktor penyebab (William, 2008). Kondisi bahwa hanya guru yang berbicara atau teachercentred merupakan faktor lain penyebab terjadinya kelas yang pasif dan kencenderungan pembelajar untuk tidak memberikan ekspresi atau pendapat sepanjang sesi banyak ditemukan di beberapa negara dengan Bahasa Inggris sebagai bahasa asing (EFL). Hal lain yang memperburuk kondisi kelas adalah kekhawatiran yang berlebih ketika melakukan kesalahan pada tata bahasa maupun pengucapan.

Faktor eksternal dan internal ini berdampak pada tingginya tingkat kecemasan pembelajar vokasi Bahasa Inggris Bisnis.

Sementara itu, keberhasilan pembelajar juga ditentukan oleh kualitas interaksi dengan rekan sejawatnya. Dukungan teman sejawat bisa memberikan dampak positif jika bisa dikelola dan dimaksimalkan dengan baik.

Pendampingan teman sejawat (mentoring) sangat potensial dilakukan mengingat pembelajar ini melakukan proses interaksi bersama-sama setiap harinya. Pendampingan ini bisa memberikan rekan sejawat perhatian serta dukungan baik verbal maupun tertulis dalam satu kurun waktu tertentu yang didalamnya berisikan rolemodelling, pembelajaran sikap belajar, serta keterampilan (Karcher, 2007).

Jika kondisi di atas dapat diwujudkan, maka pendampingan ini bisa berdampak pada munculnya caring community (Garringer and MacRae, 2008). Program pendampingan yang berasal dari teman sejawat menjadi alternatif sangat bagus 
karena pembelajar bisa bertumbuh dan mengurangi kecemasan mereka dalam menggunakan bahasa Inggris dengan bantuan dari lingkungan terdekat mereka dengan ditunjang aktivitas-aktivitas spesifik yang terstruktur dan telah dipersiapkan sehingga antar mentor dan mentee memiliki ikatan batin yang kuat dan menjadi semakin kuat dan tumbuh kepercayaan diri mereka dalam proses pembelajaran di kelas (Dubois, Holloway, Valentine, dan Cooper, 2002).

Karcher (2005) juga menyatakan bahwa peer mentoring memberikan banyak dampak positif bagi mentor dan mentee. Salah satunya adalah hubungan yang semakin erat diantara mereka yang akan menciptakan suasana saling memiliki. Ketika suasana ini muncul, sikap positif serta keterikatan untuk saling membantu juga akan terbentuk. Dikemudian hari, peningkatan nilai akademis juga bisa terjadi serta perasaan berharga pada diri sendiri juga akan terbentuk.

Adapun peran seorang mentor sendiri menurut Arevalo (2004) bisa dikategorikan sebagai berikut:

- Seorang mentor adalah seorang pemandu yang memiliki sifat caring, pembimbing yang bijaksana, sebagai rekan dalam sebuah perjalanan dan sekaligus juga teman yang dapat dipercaya.

- Seorang mentor juga bisa berperan sebagai kaca bagi mentee-nya. Mereka bisa menunjukkan siapa mereka dan bisa menjadi apa kelak dikemudian hari.

- Seorang mentor juga adalah orang yang bisa membantu mentee untuk nyaman, menunjukkan kepada mereka kesempatan-kesempatan yang ada serta cara berfikir yang positif.

- Apa yang menjadikan seorang mentor sebagai mentor sejati adalah kemampuan untuk membangun sebuah koneksi atau keterikatan diantara mereka serta menjadi katalis untuk sebuah perubahan yang positif serta tumbuh menjadi lebih baik lagi.

Berdasarkan latar belakang tersebut, penelitian ini akan memaparkan proses pendampingan sejawat dalam konteks mengurangi kecemasan berbicara Bahasa Inggris pembelajar vokasi sejak tahap awal sampai akhir serta dampak yang yang ditimbulkan dari proses ini baik bagi mentor maupun mentee.

\section{Metode}

Penelitian ini menggunakan metode kualitatif dengan menggunakan pendekatan studi kasus. Responden yang 
terlibat terdiri dari empat belas pembelajar vokasi Bahasa Inggris Bisnis yang sedang mengambil mata kuliah Speaking II. Tahapan-tahapan penting yang dilakukan meliputi:

\section{Tahap Seleksi Pendamping}

Pendamping untuk kelas Speaking II ini diambil dari mereka yang terseleksi berdasar dua kompetensi yaitu akademis secara umum termasuk didalamnya adalah kompetensi berbicara Bahasa Inggris dan kompetensi softskillsnya yaitu tingkat kepercayaan diri dan tanggung jawab yang baik.

Dari kelas ini, lima responden terpilih untuk menjadi mentor bagi rekan sejawat mereka sehingga masing-masing memiliki mentee dua sampai tiga orang.

\section{Tahap Persiapan Pendampingan}

Tahapan ini memiliki fungsi sangat penting karena didalamnya berisikan teknik dan strategi yang harus mereka lakukan dalam rangka membantu rekan sejawat mereka untuk bisa mengatasi kecemasan berbicara di depan yang lainnya. Proses bottom-up dari mentor yang terseleksi juga dilakukan dalam sesi ini untuk memberi ruang bagi mentor untuk mengungkapkan pendapat terkait teknik yang cocok untuk diaplikasikan bersama mentee mereka.

\section{Tahap Pendampingan}

Dalam empat belas kali pertemuan, mentor masuk dalam proses pendampingan bersama rekan sejawat selama tujuh kali.

\section{Tahap Monitoring Pendampingan}

Tahapan ini dilakukan untuk mengetahui kendala-kendala yang dihadapi atau dirasakan oleh mentor dan mentee. Strategi-strategi yang perlu dilakukan untuk kedepannya juga menjadi poin monitoring. Dengan demikian, kelancaran proses pendampingan dapat berjalan sebagaimana mestinya.

\section{Tahap Evaluasi Pendampingan}

Tahap ini dilakukan dua kali yaitu di tengah dan di akhir semester. Bottom-up proses dilakukan agar terjadi dinamika diskusi dan memunculkan teknik-teknik pendampingan yang dapat dikembangkan atau dihilangkan sesuai kondisi di lapangan serta bahkan evaluasi tentang penanganan kasus-kasus khusus dalam pendampingan mentee.

Untuk bahan analisa, data diperoleh dari hasil Focus Group Discussion (FGD) dengan mentor dan mentee selama dua kali (tengah semester dan akhir 
semester) saat proses monitoring dan evaluasi. Respon FGD dikategorikan dan diolah sebagai analisa fungsi pendampingan aktif dan terbimbing dalam upaya mengurangi kecemasan berbicara Bahasa Inggris responden.

\section{Hasil dan Pembahasan}

Berdasarkan respon dari FGD baik di sesi monitoring dan evaluasi, studi ini menemukan beberapa pola pendampingan sejawat yang dirasakan manfaatnya dalam membantu mengurangi kecemasan responden. Deskripsi pola pendampingan serta prosentasenya dapat dilihat pada table berikut:

\begin{tabular}{|l|l|c|}
\hline No. & \multicolumn{1}{|c|}{ Kategori Pendampingan } & $\%$ rata-rata \\
\hline 1. & $\begin{array}{l}\text { Mentor sabar dalam melayani } \\
\text { pertanyaan dari mentee }\end{array}$ & $86 \%$ \\
\hline 2. & $\begin{array}{l}\text { Keaktifan mentor bertanya } \\
\text { kondisi mentee di kelas }\end{array}$ & $79 \%$ \\
\hline 3. & $\begin{array}{l}\text { Kesiapan mentor menjawab hal } \\
\text { yang tidak diketahui mentee } \\
\text { akan satu pembahasan atau } \\
\text { topik tertentu }\end{array}$ & $71 \%$ \\
\hline 4. & $\begin{array}{l}\text { Kemampuan } \\
\text { meyakinkan mentee untuk } \\
\text { berbicara lebih aktif akan satu } \\
\text { topik speaking di grup }\end{array}$ & \\
\hline 5. & $\begin{array}{l}\text { Mentor dirasakan memiliki } \\
\text { wawasan lebih terkait topik } \\
\text { vang sedang dibahas di kelas }\end{array}$ & \\
\hline
\end{tabular}

Tabel 1. Kategori Pendampingan yang Dirasakan Positif oleh Mentee

Table 1 diatas menunjukkan lima jenis pendekatan yang memiliki dampak positif bagi mentee dalam mengatasi kecemasan berbicara Bahasa Inggris mereka di kelas. Prosentase tertinggi adalah terkait kemampuan mentor dalam meyakinkan responden untuk berbicara lebih aktif (93\%). Kalimat-kalimat seperti "This is what you want. Just let go your ideas", "No worries about grammatical mistakes", "everyone makes mistakes" merupakan contoh-contoh yang diberikan kepada mereka. Ketika ungkapan-ungkapan tersebut diberikan, mentee merasa dipercaya dan dari sini muncul kepercayaan diri mereka. Sikap sabar serta wawasan mentor (86\%) ternyata juga menjadi faktor penting dalam proses pendampingan. Melayani pertanyaan-pertanyaan atau bahkan sekedar menanyakan kepada mentee terkait topik speaking yang sedang dibahas membantu mengatasi kecemasan mereka. Disamping itu, kualitas mentor untuk siap (71\%) ketika dibutuhkan atau ada pertanyaan dari mentee serta sekedar menanyakan kondisi mereka (79\%) juga menjadi faktor penting untuk membantu mengurangi kecemasan berbicara dalam Bahasa Inggris di kelas.

Ketika ditanya tentang waktu terbaik untuk pendampingan, mentee memberikan empat variasi jawaban yang 
berbeda seperti terlihat dalam gambar berikut ini:

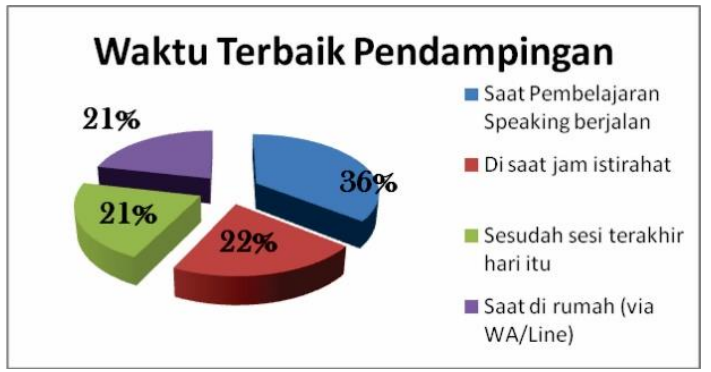

Gambar 1. Waktu Terbaik Pendampingan (Versi Mentee)

Terlihat dalam gambar di atas, prosentase terbesar adalah ketika pembelajaran speaking sedang berjalan yaitu 36\%. Saat itu, mentee biasanya berkesempatan menanyakan langsung bagaimana merangkai kalimat yang baik, pemilihan diksi untuk mengungkapkan seperti topik yang dibahas, cara mengucapkan kosakata tertentu sesuai topik, dan konfirmasi kepada pendamping apakah kalimat yang diucapkan sudah betul berdasar kaidahkaidah tata bahasa Inggris. Kedua, saat sesi istirahat (22\%) menjadi pilihan mentee untuk berdiskusi dengan pendamping. Waktu yang tidak cukup untuk berinteraksi dengan mentor serta sekedar berlatih menggunakan bahasa Inggris biasanya terjadi di saat-saat ini. Dua pilihan lain yaitu sebesar $21 \%$ adalah sesudah sesi terakhir dan ketika mereka sudah di rumah. Responden memilih kedua momen ini karena keinginan yang kuat bertanya. Memberikan ruang lebih saat sesi terakhir sekitar 15 sampai dengan 30 menit dapat memberikan mentee untuk kesempatan lain untuk bertanya. Sementara itu, interaksi virtual melalu whatsapp atau line menjadi sarana yang digunakan ketika masing-masing sudah di rumah. Diskusi lanjutan masih berlangsung dengan penggunaan media di atas.

Studi ini juga mencari informasi terkait durasi yang dibutuhkan bagi seorang mentee untuk bisa mengatasi kecemasannya.

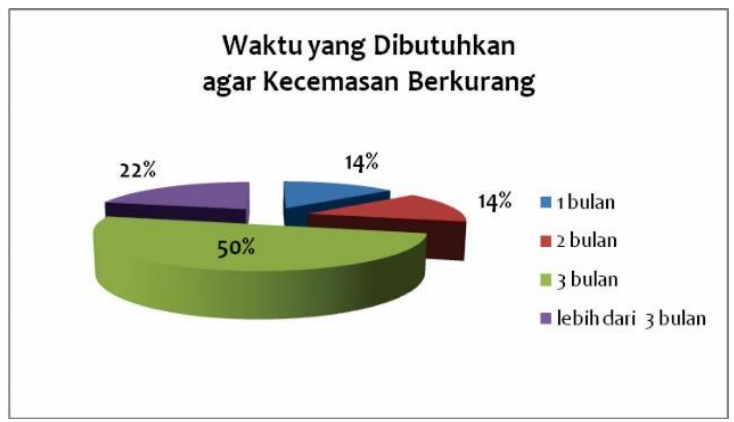

Gambar 2. Waktu yang Dibutuhkan agar Kecemasan Berkurang

Gambar di atas menunjukkan rata-rata waktu yang dibutuhkan bagi mentee untuk bisa menjadi lebih percaya diri dan mau membuka diri menggunakan bahasa Inggris mereka sehari-hari. Prosentase terbesar adalah 3. Sebanyak 50\% responden mengungkapkan bahwa mereka baru bisa mendapatkan 
kepercayaan diri mereka, jauh lebih berani mengungkapkan pendapat mereka dan terasa berkurang kecemasaannya setelah menjalani pendampingan sekitar 3 bulan. Sebesar $22 \%$ dari responden menyatakan bahwa waktu yang diperlukan untuk bisa kecemasan mereka berkurang adalah lebih dari tiga bulan. Hanya $14 \%$ dari mereka yang membutuhkwan waktu sekitar satu atau dua bulan.

Penelitian ini juga menemukan interaksi pendampingan ternyata bisa berjalan di luar kelas dengan sangat baik. Keterikatan antara mentor dan mentee dapat terjalin lebih baik karena frekuensi yang relatif sering untuk berdiskusi. Gambar 3 menunjukkan bahwasannya kebutuhan untuk tetap berdiskusi terlihat dari prosentase pertemuan tiga kali seminggu sebanyak $43 \%$. Prosentase yang sama juga untuk frekuensi lebih dari tiga kali dalam seminggu.

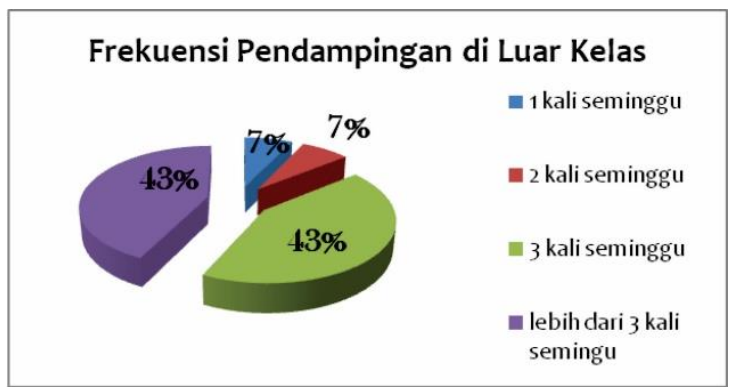

Gambar 3. Frekuensi Pendampingan di Luar Kelas Ketika ditanya lebih dalam lagi diskusi apa saja yang dilakukan antara mentor dan mentee, topik diskusi yang sering dibicarakan selain topik speaking dalam kelas adalah sebagai berikut:

\begin{tabular}{|c|c|}
\hline Topik Diskusi & Prosentase \\
\hline $\begin{array}{l}\text { Hobbies } \\
\square \quad \text { Invitation of doing the } \\
\text { hobbies together }\end{array}$ & $83 \%$ \\
\hline $\begin{array}{l}\text { Relationship } \\
\square \text { Asking further about peer } \\
\text { relationshop and special } \\
\text { relationship } \\
\square \text { Asking further about } \\
\text { parent relationship }\end{array}$ & $85 \%$ \\
\hline $\begin{array}{l}\text { Studies } \\
\square \text { Whether or not continuing } \\
\text { study at Diploma } 4 \text { or } \\
\text { Bachelor Degree (S1) }\end{array}$ & $76 \%$ \\
\hline $\begin{array}{l}\text { Internet } \\
\square \text { Further discussing on } \\
\text { game online or shopping } \\
\text { online }\end{array}$ & $85 \%$ \\
\hline $\begin{array}{l}\text { Holiday } \\
\square \text { Further discussing on } \\
\text { hanging out outside the } \\
\text { class }\end{array}$ & $74 \%$ \\
\hline
\end{tabular}

Tabel 2. Topik yang Sering Dijadikan Bahan Diskusi di Luar Kelas antara Mentee dan Mentor

Seperti tampak pada table 2 di atas, mentee cenderung suka untuk membahas lima topik seperti hobi, hubungan pertemanan, studi, internet dan liburan di luar kelas. 83\% dari responden suka membahas hobi mereka yang sama dan jika itu terkait dengan olahraga seperti bermain futsal, maka pembicaraannya berkembang ke jadwal bermain futsal bersama. Di lain pihak, cukup banyak mentee yang bersemangat ketika membahas tentang hubungan pertemanan, kesukaan pada lawan jenis 
dan kriteria-kriteria lawan jenis yang disukai. Terkadang juga, mereka membahas hubungan dengan orang tua dalam keseharian. Topik ini cukup mendapat prosentase besar yaitu $85 \%$.

Sementara itu, topik tentang studi cukup mendapatkan perhatian dalam diskusi di luar kelas. $76 \%$ responden membahas ini bersama dengan mentor mereka. Pembahasan topik ini seputar apakah mereka bisa melanjutkan ke jenjang yang lebih tinggi dalam hal ini Diploma 4 atau Strata 1. $85 \%$ responden juga mengungkapkan bahwa internet juga menjadi topik yang mereka suka bicarakan. Secara detil, kebanyakan dari mereka suka membicarakan tentang game online yang biasa mereka lakukan.

Topik yang menarik didiskusikan oleh mentor dan mentee adalah seputar liburan (74\%). Ada pembicaraan yang lebih khusus terkait upaya untuk pergi bersama ke suatu tujuan wisata atau mall di Surabaya.

Topik yang telah disebutkan di atas adalah jenis topik-topik yang biasanya dibicarakan oleh mentee kepada mentornya. Yang menarik adalah lanjutan pembahasan di luar kelas masih berhubungan dengan topik speaking yang mereka dapatkan di kelas.
Setelah berproses selama satu semester, ada beberapa catatan yang diberikan mentee kepada mentor. Catatan ini berisi harapan kepada mentor untuk periode selanjutnya atau semester selanjutnya. Lima harapan sebagai daftar teratas adalah sebagai berikut:

1. Program pendampingan diharapkan untuk dilanjutkan di semester berikutnya

2. Prodi diharapkan memfasilitasi diskusi lebih sering lagi antara mentee dan mentor sehingga hasil pendampingan bisa jauh lebih maksimal

3. Penguatan keterampilan mentoring oleh mentor di kelas.

4. Program outing bersama antar mentor dan mentee di luar kelas.

5. Pemberian insentif berupa penambahan nilai di mata kuliah Speaking untuk keaktifan mentee selama pendampingan.

Disamping proses dan hasil yang dirasakan oleh mentee, penelitian ini juga memotret dinamika perasaan yang dirasakan oleh mentor yang memberikan pendampingan kepada mentee. Seperti yang dibahas dalam metode seleksi di paparan sebelumnya, penelitian ini melibatkan lima mentor yang diambil dari 
rekan sejawat mereka berdasarkan kriteria akademis dan softskills seperti tingkat kepercayaan diri dan tanggung jawab yang baik. Oleh karena usia mentor ini sama dengan mentee yang dibimbing karena mereka satu angkatan, dinamika perasaaan yang muncul sepanjang proses pendampingan kerap terjadi dalam proses Focus Group Discussion (FGD) bersama pembimbing. Deskripsi dinamika tersebut dapat dijelaskan dalam siklus dibawah ini:

\section{Bulan pertama}

Dinamika yang ditemukan pada bulan pertama dapat dijabarkan sebagai berikut:

\section{Perasaan bangga dan senang}

Pada umumnya, kelima mentor yang telah ditunjuk ini menunjukkan perasaan bangga dan senang karena telah diberi kepercayaan untuk membantu rekan sejawatnya mengatasi kecemasan dalam berbicara Bahasa Inggris di kelas. Beberapa variasi ekspresi bangga dan senang dapat dilihat pada tabel dibawah ini.

\begin{tabular}{|c|c|}
\hline Mentor & \multicolumn{1}{|c|}{ Ekspresi } \\
\hline Mentor 1 & $\begin{array}{l}\text { "Senang bercampur bangga } \\
\text { bisa menjadi mentor buat } \\
\text { teman-teman sekelas meski } \\
\text { kurang yakin bisa, sih" }\end{array}$ \\
\hline Mentor 2 & $\begin{array}{l}\text { "terimakasih untuk } \\
\text { kesempatannya pak..dari sini, }\end{array}$ \\
\hline
\end{tabular}

\begin{tabular}{|l|l|}
\hline \multirow{2}{*}{ Mentor 3 } & $\begin{array}{l}\text { sy perlu belajar lebih lagi agar } \\
\text { bisa jadi mentor yang baik" }\end{array}$ \\
& $\begin{array}{l}\text { "saya sangat excited pak } \\
\text { karena diminta untuk jadi } \\
\text { mentor buat teman saya. } \\
\text { Mudah-mudahan saya mampu } \\
\text { ya pak" }\end{array}$ \\
\hline Mentor 4 & "sebenarnya saya merasa \\
& $\begin{array}{l}\text { kurang mampu pak. Tapi } \\
\text { karena diberi kepercayaan, sy } \\
\text { juga senang dan bangga meski } \\
\text { harus banyak belajar" }\end{array}$ \\
\hline Mentor 5 & $\begin{array}{l}\text { "Yakin dengan saya ya pak? } \\
\text { Maaf jika nantinya banyak } \\
\text { kekurangan saat membantu } \\
\text { teman ya pak. Mohon diberi } \\
\text { bimbinga agar lebih mampu } \\
\text { lagi ya pak..saya senang dan } \\
\text { bangga sekaligus juga agak } \\
\text { terbeban " }\end{array}$ \\
\hline
\end{tabular}

Tabel 3. Rekaman Ekpresi Mentor pada Bulan Pertama

Ekspresi di atas muncul setelah responden dipilih menjadi mentor bagi rekan sekelas mereka. Dari ekspresi yang terekam dalam sesi diskusi dengan mereka, perasaan senang dan bangga mewarnai ekspresi mereka. Namun, ada persepsi dari mereka bahwa mereka merasa tidak mampu dan perlu bimbingan dari dosen. Keinginan untuk belajar dari mentor terpilih terpancar sangat kuat. Dari sisi ini, pemilihan mentor memiliki dampak positif bagi mereka karena terpacu untuk belajar lagi.

\section{Bulan Kedua sampai Ketiga}

Memasuki bulan kedua dan ketiga, setelah mentor mendapatkan bimbingan serta panduan-panduan praktis menjadi 
mentor, proses pendampingan berjalan dan mulai menunjukkan dinamikadinamika tantangan bagi seorang mentor. Dalam monitoring di bulan ketiga pada sesi FGD, beragam ekspresi juga dikemukakan oleh mentor-mentor ini. Beberapa hal yang ditemukan diantaranya adalah:

\ Kecemasan dan kesulitan mentor Oleh karena frekuensi komunikasi dan interaksi yang relatif intens dengan mentee dan semakin dekatnya hubungan antara mentor dan mentee, kecemasan mentor muncul karena dipicu cukup banyaknya pertanyaanpertanyaan yang dirasakan oleh mereka sulit untuk memberikan jawaban atau respon yang tepat akan pertanyaan-pertanyaan mentee masing-masing. Kecemasan ini yang juga menjadi bagian dari kesulitan mentor dalam pendampingan.

$\square$ Tuntutan mentee

Kesan yang tertangkap dari mentee terhadap mentor adalah figur yang mampu dan lebih dari mereka. Kesan ini muncul di benak pada mentee sehingga harapan mereka terkesan demanding.
Beberapa contoh terkait hal itu diantaranya adalah ketika mentee belajar sebuah topik tentang life issues pada satu pertemuan, mentee meminta bantuan mentor untuk mencarikan kosakatakosakata yang sesuai dengan keinginan mereka. Permintaan tersebut berlanjut di luar sesi saat itu melalui whatsapp atau line. Sikap ketergantungan ini biasanya disampaikan oleh mentor kepada dosen pembimbing dan biasanya disarankan untuk dipandu agar mereka memiliki keterampilan menggunakan kamus atau mencari ide di internet.

$\square$ Kecenderungan waktu pendampingan yang berlebihan Interaksi yang baik antara mentor dan mentee serta profil mentor yang dituntut untuk ramah menjadikan terjalinnya hubungan yang baik diantara mereka. Jika tidak dikontrol maka kecenderungan yang terjadi adalah ketergantungan yang tinggi terhadap mentor. Tidak jarang mentor harus melayani pertanyaan atau sekedar memberikan respon diluar topik 
yang didiskusikan hari itu diluar jam perkuliahan. Jam-jam diskusi jika tidak dibatasi bisa terjadi antara pukul 22.00 sampai dengan 01 dini hari. Sebagian besar mentor masih mau melayani tapi juga ada yang membatasi sampai dengan pukul 23.00 karena mereka harus bekerja pada keesokan harinya.

\section{Bulan Keempat sampai Kelima}

Memasuki bulan keempat dan kelima, frekuensi diskusi sudah tidak sesering pada bulan kedua dan ketiga. Pada bulanbulan ini, mentor biasanya mengarahkan diskusi ke perpustakaan setelah usai perkuliahan. Dengan mengarahkan ke perpustakaan, waktu yang dibutuhkan biasanya cukup saat itu. Dengan strategi ini, mentee yang biasanya meminta diskusi saat malam hari relatif berkurang. Kedua, pada tahapan ini, sebagian mentee mengajak mentor untuk pergi ke suatu Mall sesudah perkuliahan atau pada jam-jam yang disepakati keduanya yaitu sore hari. Kesempatan ini dimanfaatkan oleh mentee untuk menggunakan Bahasa Inggris dengan mentor masing-masing. Mentor satu dengan yang lainnya bisa bersama-sama janjian untuk pergi ataupun setiap mentor pergi dengan mentee masing-masing.

\section{Bulan Keenam}

Pada bulan ini, mentor merasa jauh lebih ringan dalam pendampingannya karena tingkat ketergantungan mentee kepada mentor relatif berkurang. Berkurangnya ketergantungan seiring dengan berkurangnya interaksi dengan mentor. Hal ini terjadi karena perkuliahan sudah memasuki masa liburan panjang sehingga mentee lebih berfokus pada keluarga masing-masing saat liburan. Pada masa ini, rekaman ekspresi mentor bisa tergambar dalam tabel berikut ini: 


\begin{tabular}{|c|c|}
\hline Mentor & Ekspresi \\
\hline Mentor 1 & $\begin{array}{l}\text { "sebagian mentee saya sudah } \\
\text { mulai berlibur sehingga kontak } \\
\text { menjadi berkurang karena } \\
\text { mereka sudah kembali ke } \\
\text { keluarga" }\end{array}$ \\
\hline Mentor 2 & $\begin{array}{l}\text { "antara senang dan tidak } \\
\text { senang karena ada teman yang } \\
\text { biasanya diajak diskusi atau } \\
\text { meminta pendapat sekarang } \\
\text { sudah tidak ada." }\end{array}$ \\
\hline Mentor 3 & $\begin{array}{l}\text { "mentee saya masih meminta } \\
\text { agar saya tetap bersedia di } \\
\text { kontak dan ngobrol dalam } \\
\text { Bahasa Inggris meski liburan } \\
\text { dan saya sih ok ok saja” } \\
\end{array}$ \\
\hline Mentor 4 & $\begin{array}{l}\text { "wah akan ada yang hilang } \\
\text { selama liburan ini karena yang } \\
\text { biasanya WA saya akan sudah } \\
\text { berkurang... but it is ok } \\
\text { because they will return" }\end{array}$ \\
\hline Mentor 5 & $\begin{array}{l}\text { "pada akhirnya mentor bisa } \\
\text { istirahat dulu dari kejaran } \\
\text { mentee... pasti saya akan } \\
\text { merindukan komentar- } \\
\text { komentar mentee saya" }\end{array}$ \\
\hline
\end{tabular}

Tabel 4. Rekaman Ekpresi Mentor pada Bulan Keenam

Berdasarkan rekaman ekspresi di atas, hubungan yang sudah terjalin baik antara mentor dan mentee menghasilkan ikatan yang sangat positif. Sebagian besar ekspresi mentor menggambarkan bagaimana mereka merasa kehilangan meski sesaat karena jeda liburan.

Permintaan dari mentee untuk tetap menjaga kontak meski liburan merupakan dampak dari eratnya hubungan antara mentor dan mentee. Dalam hal ini, kepercayaan diri mereka terbangun serta kecemasan untuk berbicara Bahasa Inggris juga perlahan terkikis.

\section{Kesimpulan}

Speaking anxety atau kecemasan mengungkapkan pendapat di depan kelas menjadi problem umum yang ditemui dalam konteks EFL learning termasuk pembelajar vokasi di Surabaya. Kecemasan tersebut dipicu baik dari aspek internal maupun eksternal. Aspek internal sendiri berasal dari kualitas individu dalam memasuki suati lingkungan pembelajaran yang baru. Faktor-faktor seperti tingkat kepercayaan diri dan motivasi baik yang bersifat integrative maupun instrumental memiliki dampak yang luar biasa bagi si pembelajar. Latar belakang pendidikan terdahulu serta pengalaman di jenjang sebelumnya, paparan interaksi sebelum memasuki jenjang pendidikan tinggi dan masih banyak faktor lain menjadi penyumbang keberhasilan pembelajar dalam mengatasi kecemasan berbicara Bahasa Inggris di depan kelas.

Tidak hanya faktor internal, faktor eksternal juga menjadi faktor lain yang menjadikan kecemasan seseorang bertambah atau berkurang. Faktor Eksternal seperti rekan sejawat/teman sekelas bisa menjadi faktor pendukung 
yang dapat membantu mengurangi kecemasan mereka.

Keterampilan berbicara sebagai salah satu keterampilan penting bagi EFL learners khususnya lulusan vokasiyang nantinya masuk dalam dunia kerja dan berkecimpung dengan bidang-bidang yang membutuhkan komunikasi lisan menjadikan keterampilan ini sebagai salah satu keterampilan yang sulit karena speaking anxiety yang dialami oleh mereka.

Oleh karena interaksi yang intens dengan teman sejawat setiap hari, keberadaan mereka sangat penting untuk bisa membantu mengurangi kecemasan berbicara bahasa Inggris mereka. Penelitian ini bertujuan untuk mengeksplor peran pendampingan aktif teman sejawat dalam upaya mengurangi kecemasan berbicara Bahasa Inggris mahasiswa vokasi Bahasa Inggris. Pendampingan oleh rekan sejawat yang telah diseleksi berdasar kemampuan akademis dan kemampuan softskills (tanggung jawab dan tingkat kepercayaan diri yang baik) dilakukan dalam satu semester saat mereka mengambil mata kuliah Speaking II.

Hasil yang didapatkan dalam penelitian ini adalah pendampingan ini memberikan mentee kesempatan untuk secara berangsur-angsur mengurangi kecemasan mereka. Berdasar respon FGD, durasi bagi mereka sehingga kecemasan ini berkurang adalah 3 bulan dan lebih. Peran-peran pendampingan juga tidak hanya dilakukan saat mereka berproses belajar di kelas tapi juga di luar kelas dengan menggunakan teknologi whatsapp maupun Line.

Penelitian ini juga menunjukkan bahwa pertemuan di luar kelas bersama mentor memungkinkan terjadinya pengembangan diskusi dari topik yang telah dibahas di kelas. Studi ini juga menunjukkan bahwa pendampingan bisa terjadi 3 kali atau lebih dalam seminggu. Rekaman ekspresi mentor juga menjadi catatan dalam penelitian ini yaitu dinamika perasaan mentor selama proses pendampingan dalam bulan pertama sampai dengan bulan keenam. Bulan pertama merupakan masa dimana perasaan senang dan bangga sebagai mentor mewarnai pada masa itu. Semangat membantu serta kebanggan menjadi mentor menjadi faktor utama yang membuat proses pendampingan pada bulan pertama tidak terjadi hambatan yang berarti. 
Bulan kedua dan ketiga, frekuensi dan intesitas permintaan respon atas pertanyaan-pertanyaan mentee menjadi dinamika yang terjadi. Bulan keempat dan kelima menjadi masa dimana strategi membawa mentee ke perpustakaan seusai perkuliahan dan hang out pada jam-jam yang disepakati menjadi kegiatan yang terjadi pada masa ini dalam rangka menjaga hubungan dengan mentee serta membantu mereka meningkatkan kepercayaan diri mereka dalam berbicara Bahasa Inggris.

Bulan keenam menjadi momen bagi mentor cooling down karena masa liburan dan intensitas serta frekuensi komunikasi jauh berkurang karena sebagian besar dari mereka kembali ke kampung halaman masing-masing. Namun, pada masa ini juga mentor telah mendapatkan persepsi bahwa kecemasan mentee relatif berkurang dengan indikator intensitas serta frekuensi komunikasi dengan mentee. Disamping itu pula, catatan dari mentor juga mendapatkan bahwa tingkat kepercayaan diri mentee bertambah baik seiring dengan tumbuhnya hubungan yang baik dengan mentor mereka dan antar mentor.

Dengan berkurangnya kecemasan mereka oleh karena bantuan pendampingan dari teman sejawat ini serta dipersiapkannya keterampilan pendampingan, responden mengharapkan proses pendampingan dapat dilakukan di semester berikutnya. Rekomendasi untuk penelitian selanjutnya adalah agar membedakan antara pendampingan kakak kelas dan teman sejawat/sekelas bisa di kembangkan untuk mengetahui apakah ada perbedaan yang mencolok ketika pendampingan dilakukan oleh senior mereka. Kedua, jumlah responden yang dapat diperluas tidak hanya semester 2 tapi juga semester 4. Ketiga, keterlibatan serta penugasan dosen pembimbing bisa didistribusikan lebih merata agar hasil bisa lebih fokus dan maksimal.

\section{Daftar Pustaka}

Arevalo, E. (2004). Designing and Customizing Mentor Training. Folsom, CA. Center for Applied Research Solutions, Inc.

DuBois, D., Karcher, M. (2005). Handbook of Youth Mentoring. Thousand Oaks, California. Sage Publications.

Dubois, D.L, Holloway, B.E., Valentine, J.C., and Cooper, H. (2002). Effectiveness of Mentoring Programs for Youth: A Meta-Analytic Review. American Journal of Community Pschology, 30, 157-197.

Ellis, R. (2008). The Study of Second Language

Acquistion. Oxford: Oxford University Press.

Garringer, M., MacRae, P., (2008). Building 
Effective Peer Mentoring. Programs in Schools: an Introductory Guide.

Folson, C.A. The Mentoring Resources Center.

Harmer, J. (2001). The Practice of English Language Teaching -Third Edition. London: Longman.

Karcher, M.J. (2007). Research in Action: Cross-Age Peer Mentoring (No. 7 in Series). Alex Andria, V.A: MENTOR/ National Mentoring Partnership: Retrieved 8/6/08 from http://www. Mentoring.org/downloads/mentorin g-388.pdf.

Richars, J.C. (2008). Teaching Listening and Speaking: From Theory to Practice. New York: Cambridge University Press.

Ur, P. (1996). A Course in Language Teaching: Practice and Theory. Cambridge: Cambridge University Press.

Williams, K.E. (2008). Foreign Language
Learning Annxiety in Japanese EFL University Classes: Causes, Coping, and Locus of Control. Electronic Teaching Journal of Foreign Language

Volume 5 No 2, Retrived from

http://www.scribd.com/doc/3/54874/ foreign-language-learning-anxiety-inJapanese-EFL.

Woodrow, L. (2006). Anxiety and Speaking English as a Second Language. RELC Journal, Retrieved from http://rel.sagepub.com/cgi/content/a bstract $/ 37 / 3 / 308$. 